\title{
Palliative Radiation Therapy for Recurrent Ovarian Cancer: Efficacy and Predictors of Clinical Response
}

\section{Citation}

Jiang, Ginger. 2018. Palliative Radiation Therapy for Recurrent Ovarian Cancer: Efficacy and Predictors of Clinical Response. Doctoral dissertation, Harvard Medical School.

\section{Permanent link}

http://nrs.harvard.edu/urn-3:HUL.InstRepos:41973542

\section{Terms of Use}

This article was downloaded from Harvard University's DASH repository, and is made available under the terms and conditions applicable to Other Posted Material, as set forth at http:// nrs.harvard.edu/urn-3:HUL.InstRepos:dash.current.terms-of-use\#LAA

\section{Share Your Story}

The Harvard community has made this article openly available.

Please share how this access benefits you. Submit a story.

\section{Accessibility}


Palliative Radiation Therapy for Recurrent Ovarian Cancer: Efficacy and Predictors of Clinical Response

Ginger Jiang ${ }^{1}$, Tracy Balboni, MD, MPH ${ }^{1,2}$, Allison Taylor ${ }^{1}$, Larissa Lee, MD ${ }^{1}$

1Department of Radiation Oncology, Brigham and Women's Hospital/Dana-Farber Cancer Institute, Harvard Medical School, Boston, MA, USA

2Department of Psychosocial Oncology and Palliative Care, Dana-Farber Cancer Institute, Boston, MA

Conflicts of Interest Notification: None of the authors has financial interests to disclose. 


\begin{abstract}
Objective: To report response rates and predictors of response to palliative RT for recurrent ovarian cancer

Methods/Materials: Database review identified 64 patients with symptomatic ovarian cancer recurrence who received a total of 76 courses of RT for 103 indications from 3/2003-8/2014. RT indications were pain (44\%), bleeding (32\%), obstruction $(15 \%)$ or other $(9 \%)$. Responses were categorized as complete (CR), partial (PR) or none; all response (AR) was the sum of CR and PR. Response rates were compared by chi-square test. Multivariate analysis (MVA) was performed by logistic regression. Patients were followed for symptom recurrence and death. Results: Response rates were significantly higher for pain (AR 87\%) and bleeding (93\%) than for obstruction $(62 \%)$ and other $(60 \%, \mathrm{p}<0.01)$. Patients treated for pain at non-bony sites had higher response rates (AR 96\%) compared to those treated at bony sites $(75 \%, p=0.04)$. Patients with clear cell histology had the lowest response rates (AR 60\%) compared to those with serous $(82 \%)$, endometrioid $(95 \%)$ or other Müllerian histology $(85 \%, \mathrm{p}=0.01)$. Platinum status at diagnosis or the time of RT was not associated with response, nor was tumor size or number of prior chemotherapy regimens. On MVA, histology, RT indication and RT dose were independent predictors of response $($ all $\mathrm{p}<0.01)$.

Conclusions: Palliative RT provides relief of pain and bleeding in most patients with ovarian cancer recurrence. Patients with symptomatic obstruction, bony involvement and clear cell histology may experience lower clinical response rates.
\end{abstract}

Key words: ovarian cancer, radiotherapy, palliation 


\section{Introduction}

Approximately 22,300 women are diagnosed with ovarian cancer in the United States each year, of whom over $70 \%$ develop recurrent disease within 5 years following definitive treatment. ${ }^{1,2}$ Advanced ovarian cancer is often associated with a significant symptom burden, including bleeding, abdominal or pelvic pain, as well as obstructive symptoms, that negatively impacts quality of life. Systemic chemotherapy is often used in the palliative setting to manage symptoms but may be associated with cumulative toxicity. Furthermore, as patients develop recurrent disease that is resistant or refractory to platinum-based chemotherapy regimens, response rates to alternative non-platinum agents become increasingly poor. ${ }^{3-6}$

Palliative radiotherapy (RT) has been shown to be effective in providing symptom relief in recurrent ovarian cancer. Retrospective chart reviews conducted over the past 30 years have described overall clinical symptom response rates to palliative RT ranging from $70 \%$ to $100 \%$, with duration of symptom relief extending from 5 to 11 months. ${ }^{7-13}$ Unfortunately not all patients experience symptom relief. Prognostic factors associated with a beneficial response to palliative RT have not previously been well described in the literature. Some studies have suggested that certain conditions, such as obstruction, are not associated with good outcomes after palliative RT, and other predictors of clinical response or benefit have not been identified. The aim of this study is to identify patient- and treatment-related factors associated with clinical response to palliative RT in patients with advanced ovarian cancer in order to better inform physicians and patients of the anticipated clinical benefit.

\section{Materials and Methods}


Review of institutional databases at Brigham and Women's Hospital/ identified 64 patients with symptomatic recurrent ovarian cancer who received RT with palliative intent between March 2003 and August 2014. With approval of the Institutional Review Board, clinical data were abstracted from the general medical and RT records. Patients were required to have a histologic diagnosis of primary epithelial carcinoma of the ovary, fallopian tube or peritoneum and to have received at least 1 course of external beam RT with palliative intent for study inclusion. Patients with brain metastases and those who received salvage RT with curative intent were excluded. Following the completion of palliative RT, at least 1 follow-up encounter was required for adequate documentation of clinical response.

Clinical data were collected from the time of initial diagnosis, including age, tumor grade and histology, extent of surgical cytoreduction, chemotherapy type and number of regimens, as well as the time of palliative RT, including tumor size, with details of the palliative radiation course(s), including RT site, indication, dose scheme and fractionation. Tumor size at RT was determined based on radiological reports. Platinum status was determined at diagnosis and at the time of palliative RT, and categorized as platinum-sensitive, resistant or refractory. Platinumsensitive disease was defined as disease recurrence or progression more than 6 months from the time of last platinum exposure. Patients with platinum-resistant disease had a recurrence or progression-free interval of less than 6 months, and those with platinum-refractory disease had documented progression during treatment with platinum-based chemotherapy. The indications for palliative RT were categorized as pain, bleeding, obstruction or other indication. RT indication for pain was further stratified into bony vs. non-bony site, while obstruction was subgrouped as gastrointestinal, lymphatic, airway, or ureteral obstruction. 
Treatment response was defined as subjective improvement in the presenting symptom(s) based on review of the available clinical records. Responses were categorized as complete (CR), partial (PR) or none (NR). CR was defined as complete resolution of the symptom treated; PR was defined as improvement of the symptom treated without complete resolution; and NR was defined as no change or worsening of the symptom treated. All response (AR) was the sum of $\mathrm{CR}$ and PR. For patients with a CR or PR, the duration of response was defined as the interval from the last date of RT to the date of symptom recurrence or date of last follow-up without symptom recurrence. Ten patients received more than 1 course of palliative RT, including 6 who received multiple courses at the same site.

Response rates for CR, PR and NR were compared by a Pearson chi-square test for the following clinical and treatment covariates: age, stage at diagnosis, performance status at time of RT, histology, tumor grade, number of prior chemotherapy regimens, platinum status at diagnosis and time of RT, tumor size at RT, RT dose, and RT indication, as well as the subgroup of bony vs. non-bony site. Multivariate analysis was performed by logistic regression to identify independent predictors of palliative RT response. Covariates with p-values of 0.2 or less were selected for analysis; stepwise regression was performed using the backward elimination approach. Time to symptom recurrence and overall survival (OS) were calculated using the Kaplan-Meier method. OS was defined as the interval from the start of palliative RT until the date of death from any cause. Univariate analyses to identify predictors of symptom recurrence and overall survival were performed using the log-rank test. Statistical analysis was performed using JMP, v.11 (SAS Institute Inc., Cary, NC). A two-sided significance level of $<0.05$ was considered statistically significant. 


\section{Results}

Clinical and treatment characteristics at diagnosis

The clinical and treatment characteristics at initial diagnosis for the cohort of 64 patients are summarized in Table 1. The median age at diagnosis was 59.7 years. Most patients presented with advanced (Stage III/IV) disease (87\%) and high-grade histology (88\%). Chemotherapy was delivered in the adjuvant setting in 53 patients (85\%), neoadjuvant in $6(10 \%)$, and definitive in 3 (5\%); most commonly a platinum-based regimen was used (95\%). Two patients were not considered chemotherapy candidates at diagnosis. Although most patients (71\%) had platinumsensitive disease at diagnosis, clear cell histology was associated with a higher rate of platinum resistance at diagnosis (80\%) compared to serous (21\%) and endometrial (33\%) subtypes $(\mathrm{p}<0.01)$

\section{Clinical and treatment characteristics at time of palliative $R T$}

The clinical and treatment characteristics at the time of palliative RT are summarized in Table 2. The study population received a total of 76 palliative RT courses for a total of 103 indications at a median time of 38.5 months after diagnosis. At the time of palliative RT, $89 \%$ of patients had an ECOG performance status of 0-2, and had received a median of 4 prior chemotherapy regimens. The proportion of patients with platinum resistant/refractory disease increased from $33 \%$ at diagnosis to $74 \%$ at the time of $\mathrm{RT}(\mathrm{p}<0.001)$. The most common indications for palliative RT were pain (44\%) and bleeding (32\%); other indications included obstruction, neurological symptoms (Horner's syndrome), and skin erosion; 29\% of RT courses were administered for multiple indications. The most common fractionation regimen was $30 \mathrm{~Gy}$ 
in 10 fractions (29\% of RT courses), followed by 20 Gy in 5 fractions (17\%). The median duration of the palliative RT course was 13 days.

\section{Response rates to palliative $R T$}

Clinical response rates $(\mathrm{CR} / \mathrm{PR})$ to palliative $\mathrm{RT}$ varied significantly by histologic subtype ( $<<0.01$, Table 3, Figure 1). Patients with clear cell histology had the lowest rates of complete response (10\%) and all response (60\%) as compared to those with serous (CR 48\%, AR 82\%), endometrioid (CR 70\%, AR 95\%), or other Müllerian (CR 31\%, AR 85\%) histology. Response rates (CR/PR) also varied by RT indication ( $\mathrm{p}<0.01$, Table 3, Figure 2$)$, with the highest AR rates achieved for pain (87\%) and bleeding (93\%) when compared to obstruction $(62 \%)$ and other RT indications (60\%). Of the patients who received RT for pain, those with pain related to non-bony sites of disease had significantly higher AR rates (96\%) compared to those with bony involvement $(75 \%, \mathrm{p}<0.05)$. Although the small numbers precluded statistical comparison, lower response rates were observed for patients with lymphatic and ureteral obstruction compared to bowel or airway blockage.

RT dose was also associated with clinical response. Patients who received $\geq 3000$ cGy had significantly higher response rates (CR 58\%, AR 90\%) compared to those who received $<3000 \mathrm{cGy}$ (CR 34\%, AR 73\%, p=0.03). Other clinical factors including tumor size and number of prior chemotherapy regimens were not associated with response. Response rates were similar for patients with platinum-resistant disease at diagnosis and those with platinum-sensitive disease; platinum-sensitivity at the time of RT was also not associated with response. Response rates did not vary significantly with age at RT, stage, grade, or performance status (data not shown). In a MVA examining predictors of AR, the indication for palliative RT was a significant 
predictor of response, with obstruction having a lower likelihood of response than bleeding (adjusted odds ratio[AOR $]=0.09, \mathrm{p}=0.01$ ) or pain (AOR 0.28, $\mathrm{p}=0.09$ ). $\mathrm{RT}$ dose $\geq 30$ Gy was also an independent predictor of AR (AOR 3.3, $\mathrm{p}=0.045)$. When response rates were compared for CR, PR or NR, histology, indication for RT, and RT dose were all independent predictors on MVA (all $\mathrm{p} \leq 0.01)$

\section{Symptom recurrence and overall survival}

With a median follow-up time of 18 months, symptom recurrence was documented in $42 \%$ of indications ( 35 indications in 25 patients). The median time to symptom recurrence was 8.9 months after RT. Of the 51 patients who died of progressive disease, 26 (51\%) were free of recurrent symptoms at last follow-up; median time between last follow-up and death was 11 days. On univariate analysis, time to symptom recurrence was not associated with platinum sensitivity at diagnosis $(\mathrm{p}=0.3)$, histology $(\mathrm{p}=0.4)$, indication $(\mathrm{p}=0.9)$, or $\mathrm{RT}$ dose $(\mathrm{p}=0.5)$. Patients with platinum-resistant or refractory disease at the time of RT had a shorter interval to symptomatic recurrence than those with platinum-sensitive disease (3.9 vs. 9.9 months, respectively, $\mathrm{p}=0.03$ ). The median overall survival time was 11.2 months. OS was not associated with histology $(\mathrm{p}=0.4), \mathrm{RT}$ indication $(\mathrm{p}=0.4)$, platinum sensitivity at diagnosis $(\mathrm{p}=0.15)$ or at the time of $\mathrm{RT}(\mathrm{p}=0.4)$, number of prior chemotherapy regimens $(\mathrm{p}=0.3)$, tumor size $(\mathrm{p}=0.6)$ or $\mathrm{RT}$ dose $(\mathrm{p}=0.3)$. Patients with a clinical response to RT ( $\mathrm{CR}$ or PR) did have a longer median OS time than those with NR (11.6 vs. 5.2 months, respectively, $\mathrm{p}=0.04$ )

\section{Discussion}


This study reports the clinical outcomes for 64 patients with recurrent and symptomatic ovarian cancer who received radiation therapy with palliative intent for pain, bleeding, obstruction, or other symptoms. We found that palliative RT achieved symptom relief in up to $82 \%$ of patients. Patients treated for pain and bleeding had higher response rates than those treated for obstruction. Furthermore, patients who received palliative RT for pain at non-bony sites had higher response rates compared to those with pain related to bony disease, although most patients (75\%) still had clinical benefit. We also found that those with clear cell histology had the lowest clinical response rates, on the order of $60 \%$, when compared to those with serous $(82 \%)$ or endometrioid $(95 \%)$ histology. The median time to symptom recurrence after palliative RT was 8.9 months, and approximately $44 \%$ of our cohort developed recurrent symptoms.

The use of palliative RT to treat symptomatic and recurrent ovarian cancer has been reported by others in both prospective and retrospective studies. Table 4 summarizes the published literature that spans several decades. Overall clinical response rates for palliative RT in the ovarian cancer population have been described in the range of $70 \%$ to $100 \% .^{7-14}$ Of interest, one retrospective review of 14 patients with clear cell ovarian carcinoma reported treatment benefit from RT alone in only $64 \%$ of patients. This finding, which is in line with results from our study, suggests that clear cell histology may be less responsive to RT compared to other histologies. ${ }^{15}$ In general, clear cell histology has a distinct clinical behavior from high- grade serous ovarian cancer, with reported lower response rates to platinum-based chemotherapy, higher recurrence rates, and worse OS. ${ }^{20}$ However, the poor response rates to platinum- based chemotherapy and palliative radiation may be limited to those patients with gross measurable disease. In a multicenter retrospective study of 241 patients with early-stage ovarian clear cell carcinoma, adjuvant radiation after 3 cycles of carboplatin and paclitaxel was associated with a 
$20 \%$ benefit in disease-free survival at 5 years compared with 6 cycles of chemotherapy alone for women with stage IC or II disease. ${ }^{21}$ The survival benefit was most pronounced among patients with negative or unknown peritoneal cytology, perhaps the subset most likely to benefit from local adjuvant therapy when the risk of intraperitoneal dissemination is low.

Previous studies have also suggested that clinical response rates differ with indication, although variations in classification and small sample sizes have made analysis challenging. Tinger et al ${ }^{12}$ reported improvement in obstructive symptoms, a grouping that included gastrointestinal and genitourinary obstruction, in $75 \%$ of patients compared with improvement in bleeding in $100 \%$ of patients. Other studies have similarly demonstrated lower response rates in patients treated for intestinal obstruction compared with those treated for bleeding or pain. ${ }^{8,16}$ Tinger et $\mathrm{al}^{12}$ also reported poor response rates for lymphedema, with 0 of 3 patients having symptom improvement. Choan et $\mathrm{a}^{13}$ similarly described lymphedema as being minimally responsive to RT, with 5 of 5 patients achieving only PRs. By contrast, for other indications for RT such as pain and bleeding, all treated patients achieved CRs. ${ }^{13}$ Together, these studies support our finding that obstructive symptoms, including gastrointestinal and lymphatic obstruction, were less responsive to RT than were bleeding and pain. Although response to palliative RT in patients treated for pain has consistently been demonstrated, the slightly lower response rates in the subgroup of patients treated for pain at bony sites have not previously been reported, to our knowledge.

We also found that neither platinum status at diagnosis nor platinum status at the time of RT was associated with a difference in clinical response rate, although patients with platinumresistant or refractory disease at the time of RT had a shorter interval to symptomatic recurrence. Other authors have reported similar findings, in which response rates to palliative RT were 
independent of the number of prior cisplatin regimens ${ }^{9}$ and remained high in a platinumrefractory population. ${ }^{10}$

As with any retrospective study, this work is limited by the retrospective nature of this study and the heterogeneity of the patient population. Furthermore, for some subgroups defined by the indication for RT, the sample size was small, thus limiting our analysis, although several trends in the data warrant further investigation in a larger study. In addition, our study focused on a population of patients who received conventional RT most commonly delivered using standard palliative doses and fractionation regimens. The increasing use of stereotactic body RT may allow for dose escalation to symptomatic or oligometastatic disease in the pelvis, para- aortic chain, liver, lung, or other extracranial sites. In a phase 2 trial that included 25 patients with recurrent ovarian cancer, stereotactic body RT delivered in 24 Gy over 3 fractions resulted in a $96 \%$ target response rate with a 6 -month clinical benefit of $68 \%$ and no reported grade 3 acute toxicity. ${ }^{22}$ Additional study will be required to characterize the efficacy and tolerability of this emerging modality for patients with recurrent ovarian cancer.

In summary, palliative RT provided relief of pain and bleeding in most patients with symptomatic ovarian cancer recurrence and in approximately $60 \%$ of those with obstruction. Patients with pain related to non-bony sites of disease had higher response rates compared to those with pain at bony sites. Response rates were significantly lower for patients with clear cell histology and varied by RT dose. Platinum-resistant or refractory disease was not less responsive to palliative RT than platinum-sensitive disease. Further studies are needed to clarify whether the $\mathrm{RT}$ indication for various types of obstruction is associated with meaningful differences in clinical response. 


\section{References}

1. American Cancer Society: Cancer Facts and Figures 2016. Atlanta, Ga: American Cancer Society, 2016. Available online.Exit Disclaimer Last accessed June 23, 2016.

2. Heintz AP, Odicino F, Maisonneuve P, Quinn MA, Benedet JL, Creasman WT, Ngan HY, Pecorelli S, Beller U: Carcinoma of the ovary: FIGO 26th Annual Report on the Results of Treatment in Gynecological Cancer. Int J Gynaecol Obstet 2006;95:161-192.

3. Thigpen JT, Vance RB, Khansur T. Second-line chemotherapy for recurrent carcinoma of the ovary. Cancer 1993;71: 559-564.

4. Gordon AN, Fleagle JT, Guthrie D, et al. Recurrent epithelial ovarian carcinoma: a randomized phase III study of pegylated liposomal doxorubicin versus topotecan. J Clin Oncol 2001;19(14):3312-22.

5. Friedlander M, Millward MJ, Bell D, et al. A phase II study of gemcitabine in platinum pre-treated patients with advanced epithelial ovarian cancer. Ann Oncol 1998;9(12):1343-5.

6. Herzog TJ. Recurrent ovarian cancer: How important is it to treat to disease progression? Clin Cancer Res 2004;10:7439-7449.

7. Spanos WJ Jr, Wasserman T, Meoz R, Sala J, Kong J, Stetz J. Palliation of advanced pelvic malignant disease with large fraction pelvic radiation and misonidazole: final report of RTOG phase I/II study. Int J Radiat Oncol Biol Phys. 1987 Oct;13(10):1479-82.

8. May LF, Belinson JL, Roland TA. Palliative benefit of radiation therapy in advanced ovarian cancer. Gynecol Oncol 1990;37(3):408-411.

9. Corn BW, Lanciano RM, Boente M, et al. Recurrent ovarian cancer: effective radiotherapeutic palliation after chemotherapy failure. Cancer 1994;74(11):2979-2983. 
10. Gelblum D, Mychalczak B, Almadrones L, et al. Palliative benefit of external beam radiation in the management of platinum refractory epithelial ovarian carcinoma. Gynecol Oncol 1998;69(1):36-41.

11. Onsrud M, Hagen B, Strickert T. 10-Gy single-fraction pelvic irradiation for palliation and life prolongation in patients with cancer of the cervix and corpus uteri. Gynecol Oncol. 2001 Jul;82(1):167-71.

12. Tinger A, Waldron T, Peluso N, et al. Effective palliative radiation therapy in advanced and recurrent ovarian carcinoma. Int J Radiat Oncol Biol Phys 2001; 51(5):1256-1263.

13. E C, Quon M, Gallant V, Samant R. Effective palliative radiotherapy for symptomatic recurrent or residual ovarian cancer. Gynecol Oncol. 2006;102:204-209.

14. Caravatta L, Padula GD, Macchia G, Ferrandina G, Bonomo P, Deodato F, Massaccesi M, Mignogna S, Tambaro R, Rossi M, Flocco M, Scapati A, Scambia G, Pacelli F, Valentini V, Cellini N, Morganti AG. Short-course accelerated radiotherapy in palliative treatment of advanced pelvic malignancies: a phase I study. Int J Radiat Oncol Biol Phys. 2012 Aug 1;83(5):e627-31.

15. Al-Barrak J, Santos JL, Tinker A, Hoskins P, Gilks CB, Lau H, Swenerton KD. Exploring palliative treatment outcomes in women with advanced or recurrent ovarian clear cell carcinoma. Gynecol Oncol 2011;122:107-110.

16. De Meerleer G, Vandecasteele K, Ost P, Delrue L, Denys H, Makar A, Speleers B, Van Belle S, Van Den Broecke R, Fonteyne V, De Neve W. Whole abdominopelvic radiotherapy using intensity-modulated arc therapy in the palliative treatment of chemotherapy-resistant ovarian cancer with bulky peritoneal disease: a single-institution experience. Int J Radiat Oncol Biol Phys 2011;79:775-781. 
17. Fujiwara K, Suzuki S, Yoden E, et al. Local radiation therapy for localized relapsed or refractory ovarian cancer patients with or without symptoms after chemotherapy. Int J Gynecol Cancer 2002;12:250 - 6 .

18. Firat A, Erickson B. Selective irradiation for the treatment of recurrent ovarian carcinoma involving the vagina or rectum. Gynecol Oncol 2001;80:213-20.

19. Adelson MD, Wharton JT, Delclos L, et al. Palliative radiotherapy for ovarian cancer. Int J Radiat Oncol Biol Phys 1987;13:17-21.

20. Sugiyama T, Kamura T, Kigawa J, et al. Clinical characteristics of clear cell carcinoma of the ovary: a distinct histologic type with poor prognosis and resistance to platinum-based chemotherapy. Cancer. 2000;88:2584Y2589.

21. Hoskins PJ, Le N, Gilks B, et al. Low-stage ovarian clear cell carcinoma: populationbased outcomes in British Columbia, Canada, with evidence for a survival benefit as a result of irradiation. J Clin Oncol. 2012;30:1656Y1662.

22. Kunos CA, Brindle J, Waggoner S , et al. Phase II clinical trial of robotic stereotactic body radiosurgery for metastatic gynecologic malignancies. Front Oncol. 2012;2:181. 


\begin{tabular}{|c|c|}
\hline Number of patients & $64^{*}$ \\
\hline Median age at diagnosis (years) & 59.7 (range, 29.7-86.7) \\
\hline FIGO 2009 Stage & \\
\hline $\mathrm{I} / \mathrm{II}$ & $13 \%(8)$ \\
\hline III/IV & $88 \%(56)$ \\
\hline Histology & \\
\hline High grade serous & $61 \%(39)$ \\
\hline Endometrioid & $14 \%(9)$ \\
\hline Clear cell & $11 \%(7)$ \\
\hline Other & $15 \%(9)$ \\
\hline Mixed endometrioid and clear cell & $3 \%(2)$ \\
\hline Mixed endometrioid and mucinous & $3 \%(2)$ \\
\hline Mixed endometrioid and serous & $2 \%(1)$ \\
\hline Mixed serous and clear cell & $2 \%(1)$ \\
\hline Unspecified epithelial carcinoma & $5 \%(3)$ \\
\hline Tumor grade & \\
\hline G1/Low grade & $3 \%(2)$ \\
\hline $\mathrm{G} 2 /$ Intermediate grade & $9 \%(5)$ \\
\hline G3/High grade & $88 \%(51)$ \\
\hline Unknown & $9 \%(6)$ \\
\hline Extent of cytoreduction at diagnosis** & \\
\hline Optimal & $61 \%(39)$ \\
\hline Suboptimal & $13 \%(8)$ \\
\hline Unknown & $19 \%(12)$ \\
\hline None & $8 \%(5)$ \\
\hline Chemotherapy type & \\
\hline Carboplatin/paclitaxel & $78 \%(50)$ \\
\hline Carboplatin (single agent) & $5 \%(3)$ \\
\hline Carboplatin/gemcitabine & $3 \%(2)$ \\
\hline Cisplatin/paclitaxel & $3 \%(2)$ \\
\hline Cisplatin/cyclophosphamide & $3 \%(2)$ \\
\hline Other & $5 \%(3)$ \\
\hline No chemotherapy & $3 \%(2)$ \\
\hline Platinum status at diagnosis & \\
\hline Sensitive & $63 \%(40)$ \\
\hline Resistant & $19 \%(12)$ \\
\hline Refractory & $13 \%(8)$ \\
\hline Unknown & $6 \%(4)$ \\
\hline
\end{tabular}

* Reported data is per patient, not per RT course

** Including patients treated with neoadjuvant chemotherapy 


\begin{tabular}{|c|c|}
\hline Total \# of courses for 64 patients & $76^{*}$ \\
\hline Median age at RT (years) & 62.7 (range, $49.0-86.9$ ) \\
\hline ECOG Performance Status & \\
\hline 0-2: & $79 \%(60)$ \\
\hline 3-4: & $8 \%(6)$ \\
\hline Unknown & $13 \%(10)$ \\
\hline Median \# of prior chemotherapy regimens & 4 (range, $0-12$ ) \\
\hline Platinum status at palliative RT & \\
\hline Sensitive & $29 \%(22)$ \\
\hline Resistant & $45 \%(34)$ \\
\hline Refractory & $21 \%(16)$ \\
\hline Not treated with platinum-based therapy & $4 \%(3)$ \\
\hline Unknown & $1 \%(1)$ \\
\hline Median tumor size at RT $(\mathrm{cm})$ & 5.7 (range, $1.3-15.0)$ \\
\hline Median RT dose (Gy) & 30 (range, 7.5-53 Gy) \\
\hline Median number of fractions & 10 (range, $1-28)$ \\
\hline Palliative RT fractionation schemes & \\
\hline 30 Gy in 10 fractions & $29 \%(22)$ \\
\hline 20 Gy in 5 fractions & $17 \%(13)$ \\
\hline 8 Gy in 1 fraction & $8 \%(6)$ \\
\hline Other & $46 \%(35)$ \\
\hline Indications for palliative $\mathrm{RT}^{* *}$ & \\
\hline Pain & $44 \%(45)$ \\
\hline Bleeding & $32 \%(33)$ \\
\hline Obstruction & $15 \%(15)$ \\
\hline Horner's syndrome & $3 \%(3)$ \\
\hline Skin erosion & $2 \%(2)$ \\
\hline Other*** & $5 \%(5)$ \\
\hline
\end{tabular}

* Reported data per RT course ** $29 \%$ of RT courses were administered for multiple indications.

*** Other indications included urinary frequency, abdominal distention, hypercalcemia, nausea, and cough. 


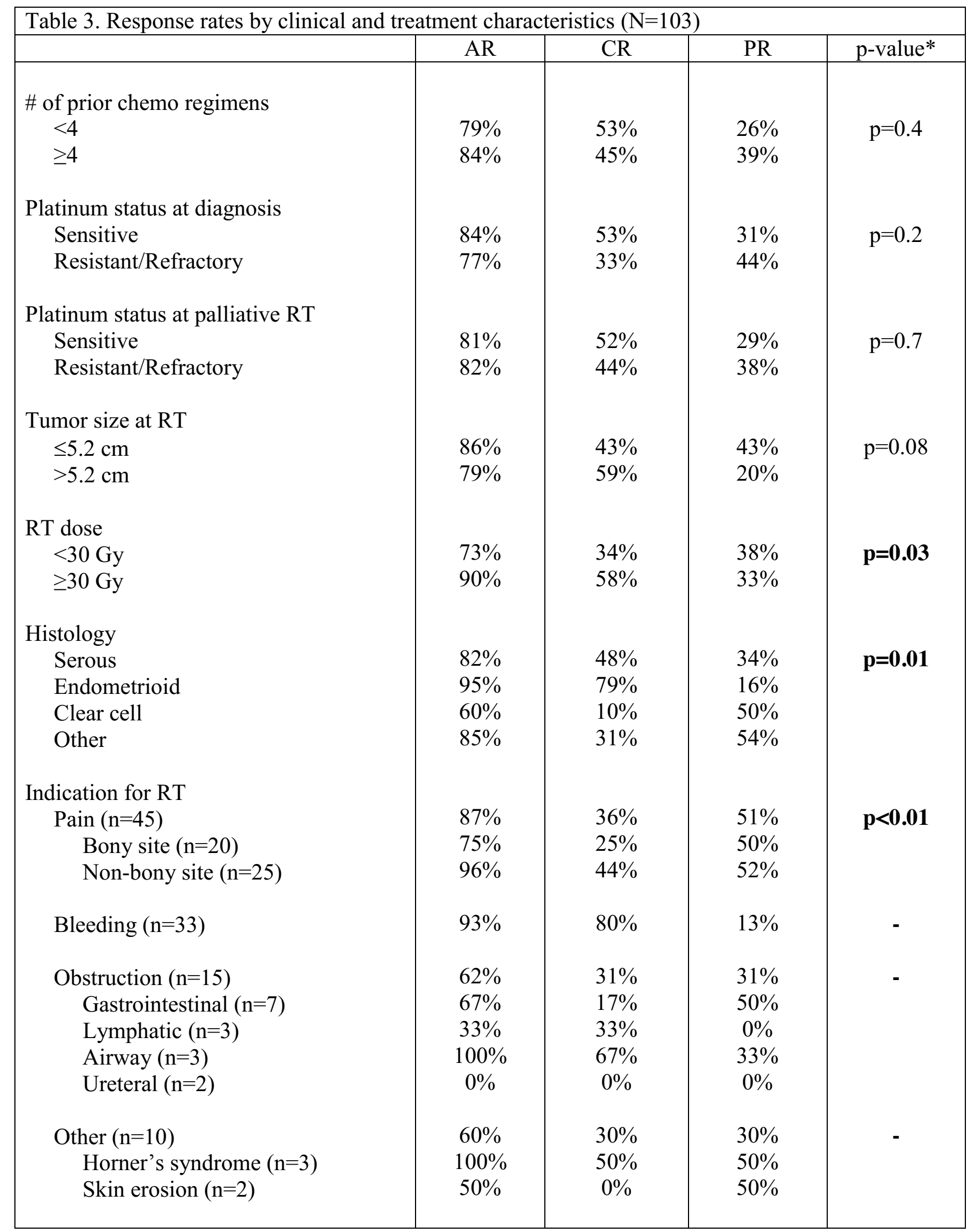

Abbreviations: AR, all response; $\mathrm{CR}$, complete response; $\mathrm{PR}$, partial response.

*p-value for comparison of CR, PR and NR rates 
Table 4. Summary of prior studies on palliative RT in advanced ovarian cancer

\begin{tabular}{|c|c|c|c|c|c|c|c|c|}
\hline Study & $\begin{array}{l}\text { No. of } \\
\text { Pts } \\
\text { (RT } \\
\text { courses) }\end{array}$ & Study type & Patient population & $\begin{array}{c}\% \\
\text { AR }\end{array}$ & $\begin{array}{l}\text { \%AR } \\
\text { for } \\
\text { pain }\end{array}$ & $\begin{array}{c}\% \mathrm{AR} \\
\text { for } \\
\text { bleeding }\end{array}$ & $\begin{array}{l}\text { Median } \\
\text { duration of } \\
\text { response } \\
\text { (weeks) }\end{array}$ & $\begin{array}{l}\text { Other predictors of } \\
\text { response }\end{array}$ \\
\hline $\begin{array}{l}\text { Caravatta } \\
(2012)^{14}\end{array}$ & $13(13)$ & $\begin{array}{l}\text { Phase I study of } \\
\text { short-course } \\
\text { accelerated RT }\end{array}$ & $\begin{array}{l}\text { Pelvic malignancies } \\
\text { (48\% with } \\
\text { gynecologic } \\
\text { tumors) }\end{array}$ & $89 \%$ & $91 \%$ & $100 \%$ & 21.5 & - \\
\hline $\begin{array}{l}\text { Al-Barrak } \\
(2011)^{15}\end{array}$ & $14(14)$ & Retrospective & $\begin{array}{l}\text { Pts with clear cell } \\
\text { ovarian ca treated } \\
\text { with chemotherapy, } \\
\text { RT alone, or both }\end{array}$ & $64 \%$ & - & - & - & - \\
\hline $\begin{array}{l}\text { De Meerleer } \\
(2011)^{18}\end{array}$ & $13(13)$ & Retrospective & $\begin{array}{l}\text { Pts with peritoneal } \\
\text { disease treated w/ } \\
\text { whole } \\
\text { abdominopelvic RT }\end{array}$ & $100 \%$ & $\begin{array}{l}75 \% \\
(3 / 4)\end{array}$ & $\begin{array}{l}100 \% \\
(2 / 2)\end{array}$ & 24.0 & $\begin{array}{l}67 \% \text { response rate }(4 / 6) \text { in } \\
\text { pts treated for intestinal } \\
\text { obstruction. }\end{array}$ \\
\hline $\begin{array}{l}E \\
(2006)^{13}\end{array}$ & $53(62)$ & Retrospective & $\begin{array}{l}\text { Pts who received } \\
\text { palliative RT for } \\
\text { ovarian cancer }\end{array}$ & $100 \%$ & $\begin{array}{l}100 \% \\
(23 / 23)\end{array}$ & $\begin{array}{c}100 \% \\
(25 / 25)\end{array}$ & 20.8 & $\begin{array}{l}\text { Only partial response was } \\
\text { achieved in pts treated for } \\
\text { lymphedema }(5 / 5) \text {. }\end{array}$ \\
\hline $\begin{array}{l}\text { Fujiwara } \\
(2002)^{19}\end{array}$ & $14(14)$ & $\begin{array}{l}\text { Phase II study of } \\
\text { local RT }\end{array}$ & $\begin{array}{l}\text { Pts with relapsed } \\
\text { ovarian cancer }\end{array}$ & $50 \%$ & $\begin{array}{l}80 \% \\
(4 / 5)\end{array}$ & $\begin{array}{l}100 \% \\
(1 / 1)\end{array}$ & - & $\begin{array}{l}\text { Symptoms of pressure and } \\
\text { obstruction had poor } \\
\text { response rates; } 25 \%(1 / 4) \\
\text { and } 0 \%(0 / 2) \text { respectively. }\end{array}$ \\
\hline $\begin{array}{l}\text { Firat } \\
(2001)^{20}\end{array}$ & $23(23)$ & Retrospective & $\begin{array}{l}\text { Pts with recurrent } \\
\text { ovarian cancer } \\
\text { involving the } \\
\text { vagina or rectum }\end{array}$ & $79 \% *$ & - & $\begin{array}{l}100 \% \\
(8 / 8)\end{array}$ & 1.46 years & $\begin{array}{l}70 \% \text { CR rate was achieved } \\
\text { in platinum-refractory } \\
\text { patients. }\end{array}$ \\
\hline $\begin{array}{l}\text { Tinger } \\
(2001)^{12}\end{array}$ & $72(72)$ & Retrospective & $\begin{array}{l}\text { Pts who received } \\
\text { palliative RT for } \\
\text { ovarian cancer }\end{array}$ & $73 \%$ & $\begin{array}{c}77 \% \\
(17 / 22)\end{array}$ & $\begin{array}{l}100 \% \\
(7 / 7)\end{array}$ & 38.7 & $\begin{array}{l}\text { Obstruction had a response } \\
\text { rate of } 75 \%(9 / 12) .0 / 3 \\
\text { patients with lymphedema } \\
\text { had symptomatic relief. }\end{array}$ \\
\hline $\begin{array}{l}\text { Gelblum } \\
(1998)^{10}\end{array}$ & $33(33)$ & Retrospective & $\begin{array}{l}\text { Pts who received } \\
\text { palliative RT for } \\
\text { platinum-refractory } \\
\text { ovarian cancer }\end{array}$ & $94 \%$ & $\begin{array}{l}100 \% \\
(5 / 5)\end{array}$ & $\begin{array}{l}100 \% \\
(9 / 9)\end{array}$ & 47.9 & $\begin{array}{l}1 \text { patient treated for leg } \\
\text { edema had a partial } \\
\text { response. }\end{array}$ \\
\hline $\begin{array}{l}\text { Corn } \\
(1994)^{9}\end{array}$ & $33(47)$ & Retrospective & $\begin{array}{l}\text { Pts who received } \\
\text { palliative RT for } \\
\text { platinum-refractory } \\
\text { ovarian cancer }\end{array}$ & $70 \%$ & $\begin{array}{c}83 \% \\
(15 / 18)\end{array}$ & $\begin{array}{l}90 \% \\
(9 / 10)\end{array}$ & 17.4 & $\begin{array}{l}\text { Overall response rates were } \\
\text { not associated with } \\
\text { histologic differentiation or } \\
\text { number of previous cisplatin } \\
\text { regimens. }\end{array}$ \\
\hline $\begin{array}{l}\text { May } \\
(1990)^{8}\end{array}$ & $26(43)$ & Retrospective & $\begin{array}{l}\text { Pts who received } \\
\text { palliative RT for } \\
\text { ovarian cancer }\end{array}$ & $65 \%$ & $\begin{array}{c}67 \% \\
(12 / 18)\end{array}$ & $\begin{array}{l}80 \% \\
(4 / 5)\end{array}$ & - & $\begin{array}{l}\text { Response rates for GI } \\
\text { obstruction and } \\
\text { lymphedema were } 64 \% \\
(7 / 11) \text { and } 0 \%(0 / 2) \\
\text { respectively. }\end{array}$ \\
\hline $\begin{array}{l}\text { Adelson } \\
(1987)^{21}\end{array}$ & $34(34)$ & Retrospective & $\begin{array}{l}\text { Pts who received } \\
\text { palliative RT (large } \\
\text { single fraction RT } \\
\text { or maximum of } 3 \\
\text { fractions) for } \\
\text { ovarian cancer }\end{array}$ & $59 \%$ & $\begin{array}{c}55 \% \\
(11 / 20)\end{array}$ & $\begin{array}{c}71 \% \\
(15 / 21)\end{array}$ & - & $\begin{array}{l}\text { Response rate for edema } \\
\text { was } 20 \%(1 / 5) \text {. }\end{array}$ \\
\hline
\end{tabular}

*Complete Response (CR) rate reported 
Figure 1. Response rates to palliative RT by histology

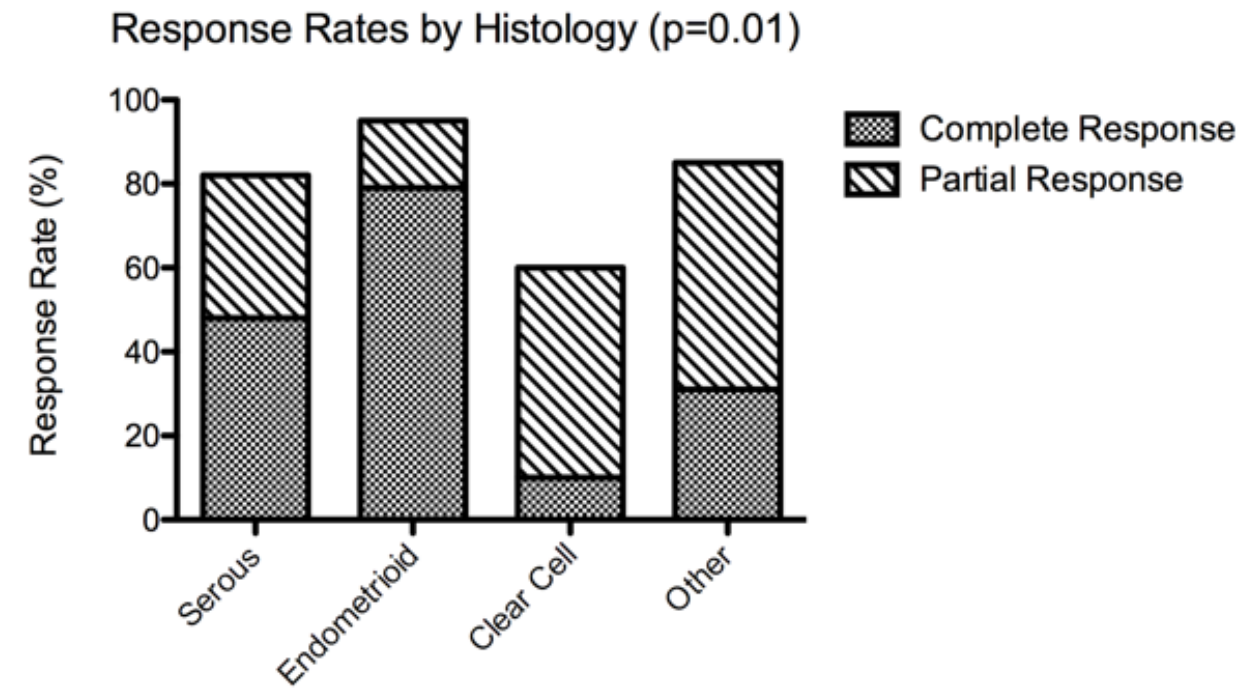

Figure 2. Response rates to palliative RT by indication

Response Rates by Indication $(p<0.01)$

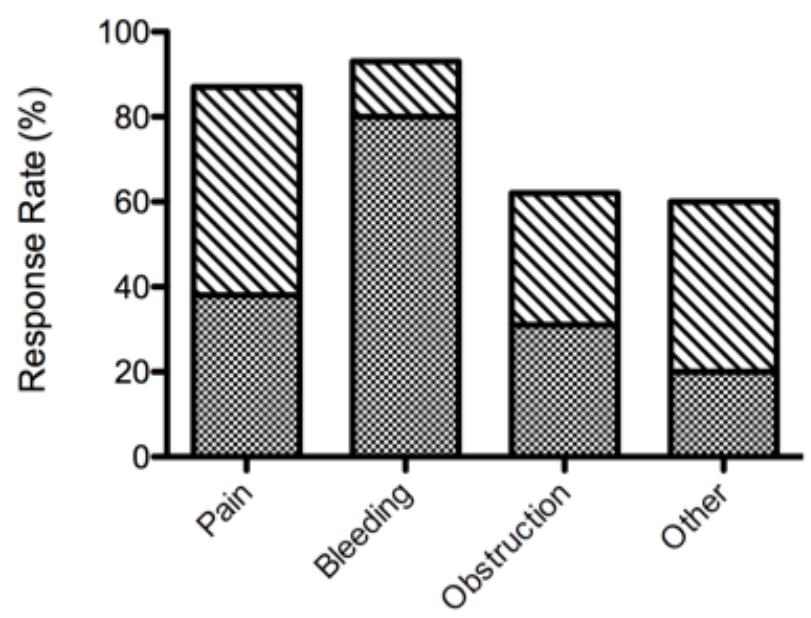

冈 Complete Response

W Partial Response 